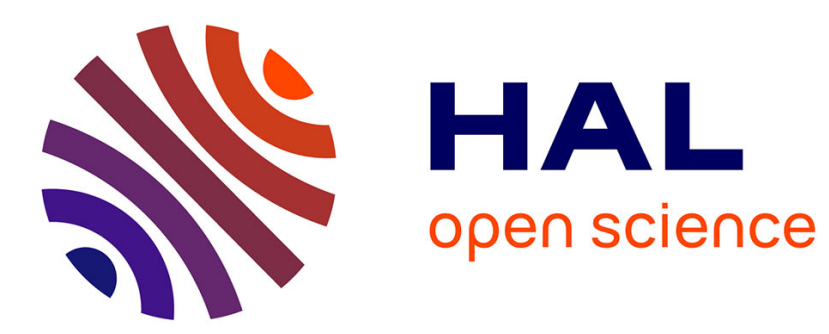

\title{
The Political Economy of Revolution and Institutional Change: the Elite and Mass Revolutions
}

\author{
Mehrdad Vahabi, Philippe Batifoulier, Nicolas da Silva
}

\section{To cite this version:}

Mehrdad Vahabi, Philippe Batifoulier, Nicolas da Silva. The Political Economy of Revolution and Institutional Change: the Elite and Mass Revolutions. Revue d'Economie Politique, 2020, 130 (6), pp.855-889. hal-03228435

\section{HAL Id: hal-03228435 \\ https://hal.science/hal-03228435}

Submitted on 18 May 2021

HAL is a multi-disciplinary open access archive for the deposit and dissemination of scientific research documents, whether they are published or not. The documents may come from teaching and research institutions in France or abroad, or from public or private research centers.
L'archive ouverte pluridisciplinaire HAL, est destinée au dépôt et à la diffusion de documents scientifiques de niveau recherche, publiés ou non, émanant des établissements d'enseignement et de recherche français ou étrangers, des laboratoires publics ou privés. 


\title{
The Political Economy of Revolution and Institutional Change: the Elite and Mass Revolutions
}

\author{
Mehrdad Vahabi, Philippe Batifoulier and Nicolas Da Silva
}

\begin{abstract}
In this paper, we question a very deep-rooted bias in the economic literature with regard to conflict and revolution. Conflict in general and revolution in particular are not necessarily 'dark side of self-interest' or bad things. They may be sources of political and economic efficiency depending on their incidence on institutional change. Revolution escapes from Hirschman's dichotomous corrective mechanisms of 'voice' versus 'exit'. We consider revolution as scream exiting from existing rules and voicing new rules. Our theoretical framework suggests that revolutions are a source of institutional innovation characterized by a process of deinstitutionalization and re-institutionalization. The Veblenian 'selective adaptation' on the basis of differentiation, inheritance and selection through a survival struggle provides an endogenous explanation of its different stages. We explore the impact of revolutions on institutional change by focusing on two major types of revolutions, namely the elite revolution and the mass revolution. The former is led by a fraction of the old elite group, while the latter is driven by social groups and classes that were previously non-dominant. The 1688 British Glorious Revolution and the 1789 French Revolution are emblematic figures of these two types of revolutions. The great demarcation between property and sovereignty was accomplished by both revolutions traversing through different patterns of institutional innovation. Our references to the British revolution are exclusively limited to old and new institutionalist authors to show the consistency between their theoretical framework and conflict as a means of bargaining. By contrast, our analysis of French revolution tries to test the consistency of our theoretical framework in light of empirical evidence.
\end{abstract}

Keywords: British Glorious Revolution, de-institutionalization and re-institutionalization, Elite Revolution, French Revolution, Mass Revolution, Paradox of Collective Action, Political Coase Theorem, Scream

JEL Classification: D02, D62, D70, D74, D79, H10, H11, H41, K11, L14, N40, N41, O57, P16

\section{Economie politique de la Révolution et du changement institutionnel : Révolutions d'élites et Révolutions de masse}

\section{Résumé}

Dans cet article nous interrogeons une difficulté profonde de la littérature économique portant sur les questions du conflit et de révolution. Le conflit en général et la révolution en particulier ne sont pas nécessairement négatifs ou le «côté obscur de l'intérêt personnel » ou de mauvaises choses. Ils peuvent être la source d'efficacité politique et économique en fonction de leur 
incidence sur le changement institutionnel. La révolution échappe à la dichotomie d'Hirschman sur les mécanismes correctifs, prise de parole (voice) versus défection (exit). Nous considérons la révolution comme un cri ou hurlement (scream) qui conduit à rejeter les règles du jeu existantes et à proposer de nouvelles règles du jeu. Notre cadre théorique suggère que les révolutions sont une source d'innovation institutionnelle caractérisée par un processus de dé-institutionnalisation et de ré-institutionnalisation. La sélection adaptative, au sens de Veblen, fondée sur la différenciation, l'héritage et la sélection via une lutte pour la survie, fournit une explication endogène à ces processus. Nous explorons alors l'impact de la révolution sur le changement institutionnel en nous intéressant à deux types de révolutions, les révolutions d'élite et les révolutions de masse. Les premières sont dirigées par une fraction des anciennes élites, tandis que les secondes sont guidées par des groupes sociaux et des classes sociales qui étaient auparavant non dominantes. La Glorieuse révolution britannique de 1688 et la Révolution française de 1789 sont des figures emblématiques de ces deux types de révolutions. La séparation entre la propriété et la souveraineté a été accomplie par ces deux révolutions mais par différentes voies d'innovations institutionnelles. Nos références sur la Révolution britannique sont exclusivement limitées aux anciens et aux néo-institutionnalistes afin de discuter leur cadre théorique et une conception du conflit centrée sur la négociation. Notre analyse de la Révolution française s'appuie sur notre propre cadre théorique et sur les éléments de preuve empiriques disponibles dans littérature historique.

Mots clés : Glorieuse révolution britannique, dé-institutionnalisation et ré-institutionnalisation, révolution d'élite, Révolution française, révolution de masse, paradoxe de l'action collective, théorème politique de Coase, scream.

\section{Acknowledgments}

We wholeheartedly thank, the editor of Revue d'Economie Politique, Bertrand Crettez, and the editing manager Tarik Tazdait, for their excellent and constructive detailed comments. We would also like to present our gratitude to Bernard Chavance, Claude Ménard, Antoine Pietri, Nicolas Pinsard, Emma Tyrou, and Mandana Vahabi, for their inspiring and insightful remarks on earlier versions of this paper. Obviously, all the remaining errors are ours. 


\title{
The Political Economy of Revolution and Institutional Change: the Elite and Mass Revolutions
}

\author{
Mehrdad Vahabi ${ }^{1}$, Philippe Batifoulier ${ }^{2}$ and Nicolas Da Silva ${ }^{3}$
}

\section{Introduction}

While revolution brings down the political system, it is in its turn a source of Sovereignty or 'true state' combining coercion with recognition of rights for citizens. This was John Commons's appraisal (1899-1900/1965) of the British Glorious Revolution of 1688-89 ${ }^{4}$. Karl Marx (1852/1999) emphasized the role of all revolutions including the 1789 French Revolution in creating and completing the state machinery: "The first French Revolution developed centralization, but at the same time it increased the extent, the attributes and the number of agents of governmental power. Napoleon completed this state machinery. The legitimate monarchy and the July monarchy added nothing but a greater division of labor...Finally, in its struggle against the revolution, the parliamentary republic found itself compelled to strengthen, along with repressive measures, the resources and centralization of governmental power. All revolutions perfected this machine instead of smashing it. The parties that contended in turn for domination regarded the possession of this huge state edifice as the principal spoils of the victor." (Emphases are added).

Charles Tilly (1985) claimed that war created the state in Western Europe. Although it may seem paradoxical, we opine that it was also revolution that created the state in Western Europe, or at least in England and France. The role of revolution in institution-building is not limited to the state; it also instituted the uniform system of weights and measures known as the metric system (Brinton, 1938/1952, pp. 266-67) as well as many 'invented traditions' ${ }^{5}$ such as primary education, public ceremonies (such as Bastille Day), and mass production of public monuments (Hobsbawm and Ranger, 1988, pp. 270-71).

But if revolution generates sovereignty and secure property rights, why it should not be treated as a possible avenue for economic efficiency and positive institutional change? This is the first issue that will be examined in this paper. This paper explores the impact of revolutions on institutional change by focusing on the British Glorious Revolution of 1688-1689 and the French Revolution in 1789 .

There is not such a thing as 'revolution' proper; we had 'revolutions'. Political scientists had distinguished two general types of revolution: an 'elite' revolution from above (Trimberger,

${ }^{1}$ CEPN, Université Sorbonne Paris Nord, Email : mehrdad.vahabi@wanadoo.fr

${ }^{2}$ CEPN, Université Sorbonne Paris Nord, Email : philippe.batifoulier@univ-paris13.fr

${ }^{3}$ CEPN, Université Sorbonne Paris Nord, Email : nicolas.dasilva@univ-paris13.fr

${ }^{4}$ We will discuss Commons's idea about the British Revolution with regard to sovereignty and property in more detail in section 2.2.

${ }^{5}$ Invented traditions are "a set of practices normally governed by overtly or tacitly accepted rules and of a ritual or symbolic nature, which seek to inculcate certain values and norms of behavior by repetition, which automatically implies continuity with the past...Revolutions and 'progressive movements' which break with the past, by definition, have their own relevant past, though it may be cut off at a certain date such as 1789." (Hobsbawm and Ranger, 1988, pp. 1-2). 
1972), and a revolution 'from below' (Skocpol, 1979). A salient illustration of the latter is the French Revolution of 1789. The British Glorious Revolution of 1688-1689 can be classified as an elite revolution. Drawing upon vast empirical evidences regarding revolutions in the past and present, Goldstone (2009) suggests a distinction between 'color' and 'radical' revolutions that cover the previous typology of revolutions as 'elite' and 'mass'.

The advocates of Political Coase Theorem, like North (1981, 1990a, b) and North et al. (2009) acknowledge the role of elites and elite revolutions notably the 1689 British Glorious Revolution in instigating institutional change. This type of revolution is a source of institutional innovation since it comes within the scope of elites' bargaining process. But they exclude masses from making history because of free-riding problem: "institutional innovation will come from rulers rather than constituents since the latter would always face the free rider problem" (North, 1981, p. 32). But why free-riding problem could not shun the outburst of mass revolutions such as the French Revolutions of 1789 and 1871 ?

A second contribution of this paper is to explore how the collective action dilemma can be resolved in mass revolutions. In doing so, we will identify specific characteristics of mass revolutions. The class-orientation and the polarization processes will be identified as major differences of mass revolutions compared to elite revolutions.

In fact, both types of revolutions have extensively contributed to what North calls 'institutional innovation'. The last contribution of this paper is to study revolution as a process of institutional innovation. We argue that this type of innovation is similar to the Schumpeterian 'creative destruction" ${ }^{\prime 6}$ by replacing new institutions instead of the old ones. It embraces two complementary processes: de-institutionalization and re-institutionalization. What are the different stages of this process and how can its inner dynamic be explained? It will be shown that the re-institutionalization process in mass revolutions are determined by two factors: 1) the lack of economic conditions for redistributive policies pursued by 'radicals'; 2) the interaction between new powerholders lacking economic power, and the economically strong propertyholders with a dearth of political power. We will discuss this process in detail with regard to the 1789 French Revolution.

The paper is structured in the following way. First section clarifies what we mean by revolution in conjunction with institutions and institutional change. Second section examines the British Glorious Revolution of 1688-1689 in light of transaction cost economics and Political Coase Theorem (PCT). Bargaining rather than conflict is the focus of this literature which is consistent with elite revolutions. Section 3 explores revolution as a process of de-institutionalization and reinstitutionalization, and distinguishes two different patterns of institutional change according to elite and mass revolutions. Discussing collective action dilemma in case of mass revolutions, we borrow Vahabi's (2004) theory of destructive power to explain why it is less relevant for a 'rejection' political platform than it is for a 'positive' one. We then explain the evolutive impact

\footnotetext{
${ }^{6}$ In contrast to Schumpeter (1951) for whom 'creative destruction' even in product innovation was rather an incremental process, we acknowledge both gradual and revolutionary dimensions of such a process. Unfortunately, one of the shortcomings of Schumpeter was that he disregarded institutional innovation.
} 
of mass revolutions on institutional change on the basis of the Veblenian 'selective adaptation' containing variation, inheritance and selection through a survival struggle. In section 4, we apply our analytical framework to the 1789 French Revolution in order to illustrate the specific characteristics of mass revolutions with regard to institutional change. A short conclusion will follow.

\section{Section 1. Revolution and institutions}

The two key concepts in this paper are revolution and institution. What do they mean and what is their relationship? In this first section, we scrutinize the meaning of revolution in relation with institutions and institutional change.

\subsection{Revolution: from institutional vacuum to institutional innovation}

According to Commons, the institution is "collective action in restraint, liberation, and expansion of individual action." (1934/1961, p. 73). Undoubtedly, revolution is a collective action. But can it be pigeonholed as 'institution'? Advocates of a comprehensive definition of institution ${ }^{7}$ who replace the term 'social' with 'institutional', and reduces all forms of social relationships to institutional relationships, might describe revolution as a particular form of institution. But it is hard to consider revolution as an institution, since the very existence of a revolution implies the lack of state authority, different degrees of anarchy, or an institutional vacuum. Reviewing the experience of revolutions in the ex-Socialist countries, Janos Kornai wrote: "Many people had the naïve idea that the elimination of central planning and bureaucratic coordination would be followed immediately and automatically by the appearance and operation of market coordination. In fact, there is a curious 'no man's land,' where bureaucratic coordination no longer applies and market coordination does not yet apply, and economic activity is impeded by disintegration, lack of coordination, and anarchy." (1995, p. 178).

That is true, a revolution ushers in a period of 'no man's land' during which the old rules lose their power to maintain the old order but the nascent rules are still too weak to establish a new one. This situation is often characterized as a 'dual' power. Furet also defines the French revolution in these terms: "The revolution represents the moment when the old tipped over towards the new and thus also the abolition of the former and the arrival of the latter." (1998, p. 55). Hence, revolution is a collective action but not an institution that may be better defined as a

\footnotetext{
${ }^{7}$ See Chavance (2012, pp. 44-45) for a distinction between a 'comprehensive' and a 'more bounded' definition of institution. A comprehensive definition includes language, money, law, the state and organizations in an extended concept of institution. In contrast to this definition, a more bounded definition gives a great strength to the conceptual scheme. For example, Commons focuses on an organizational interpretation of institutions, and North (1990a) explicitly differentiates between institutions as 'rules of the game' and organizations as 'players'. We adopt a more bounded definition of institution as a repeated social interaction (and not just collective action) with established formal or informal rules. In our perspective, institutional relationships are only part of social relationships that are not necessarily institutionalized. Michael Mann underlines this point in analyzing historical processes. For him societies as 'organized power networks' often escape from institutionalization: "The driving forces of human society is not institutionalization. History derives from restless drives that generate various networks of extensive and intensive power relations. These networks have a more direct relation to goal attainment than institutionalization has." (1986, p. 15). In fact, non-institutionalized social relationships such as wars and revolutions play a key role in the emergence and evolution of institutions.
} 
repeated collective action or an order. In fact, institution is not merely a collective action, it is rather a repeated collective action. As North (1988, p. 15) aptly noted: "By institutions, I mean the humanly devised constraints on repeated human interactions, that is, the rules of the gameboth formal and informal norms of behavior and the way they are enforced." (Emphases are added $)^{8}$. Institutions are 'repeated' human interactions and that explains why they can make the outcome of these interactions predictable to some extent without eliminating uncertainties. Revolution is not a repeated collective action, it is a singular event, and that is why it is unpredictable and irreducible to any type of institutions, although there are institutions such as political parties that play an important role in revolutions ${ }^{9}$.

The revolutions against the Soviet system also demonstrated the importance of fundamental institutional change. Kornai underlined this point in his analysis regarding the difference between 'reform' and 'revolution': "While reform yields important changes, it retains the fundamentals of the system concerned. Revolution, on the other hand, changes the fundamentals radically, so bringing about a change of system" (Kornai, 1991, p. 50). By 'fundamentals', Kornai means the three first blocks of major institutions, i.e., politics and ideology, property ownership, and the predominant coordination mechanism. Applying this approach to the Soviet system, it implies that reform (for example perestroika initiated by Gorbatchev in Russia) did not undermine those fundamental blocks, whereas revolution required the end of undivided political power by the Communist Party, the termination of the state as the main property owner, and, accordingly, the replacement of bureaucratic coordination with market coordination.

To put it differently, reform aimed at major changes in the ex-Soviet system, whereas revolution started a transformation that ultimately shifted the country in question away from socialism. Thus, the difference between reform and revolution did not lie in the speed or in the method of transformation: "The distinction is not that a reform is peaceful and a revolution violent and bloody. The process of reform may also be induced by bloody uprisings, and those impeding it may use violence against the reformers; a revolution, on the other hand, may take place without bloodshed. The difference lies in how superficial or deep the change is. To use a Hegelian expression here, revolution brings a qualitative change" (Kornai, 1991, p. 51). Of course, in terms of Kornai's value judgments, the most attractive form of revolution is peaceful, similar to what happened in Prague during the "Velvet Revolution"10.

\section{1-2. Revolutions as scream}

In Hirshleifer's (2001) terminology, conflict stems from the 'dark side' of self-interest. "We think of conflicts in terms of family quarrels, separations, and divorce, or racial discrimination and race riots, or industrial disputes and strikes, or political conflict and revolution, or

\footnotetext{
${ }^{8}$ In contrast to Commons, for North, institutions are a "set of rules" that shape collective action. What the rules are, is not our concern in this discussion. The important issue is to distinguish a "repeated" collective action from a "non-repeated" collective action such as revolution.

${ }^{9}$ We owe to Chavance for reminding us the name of a Mexican political party (PRI), "Party of the Institutionalized Revolution", founded in 1929 that held uninterruptedly power in the country for 71 years (1929-2000). In this case, it is the Party that led the revolution that has been "institutionalized".

${ }^{10}$ For an examination of Kornai's revolutionary perspective regarding the transformation of the Soviet type system, see Vahabi 2019.
} 
international conflict and war. These things we think of on the whole as bad, as tending to go too far and to get out of hand." (Boulding, 1962, pp. 306-307). But why all kinds of conflicts should be considered as 'dark side of self-interest' or as bad things? Are social conflicts necessarily bad?

In the economic literature, Hirschman is one of the exceptions in identifying the positive or productive dimension of the social conflict. He $(1970,1974)$ suggested that voice or non-violent conflictual activity of employees (strikes, protestation, etc.) might be a source of efficiency in an enterprise. Hirschman's starting point was the insufficiency of market coordination and especially the limits of the 'exit' mechanism. He introduced 'voice' as a complementary mechanism to overcome this insufficiency. While 'exit' belongs to economics, 'voice' is political action par excellence. He compared these two 'correcting mechanisms' ('exit' and 'voice') and argued that market failure is not limited to the presence of externalities. Where 'exit' does not do a good job of stirring up management and restoring efficiency, 'voice' can replace it. In other words, 'voice' or conflictual activity within the existing rules is not necessarily counterproductive. It may contribute to improve economic efficiency, and should be thus classified as a corrective reform mechanism. This theory can be applied to advocacy in civil rights movements and also participatory democracy. Hirschman derives the positive dimension of social conflict from its ability to improve the existing institutions.

Despite its richness, Hirschman's concept of voice is ambiguous because he confuses, in our understanding, two different kinds of voice: 1) voice within the existing rules, e.g., a protest or a reformist movement within a political regime or an organization; and 2) voice against the existing rules, for example civil disobedience, coup d'état or revolution (Vahabi, 2016, pp. 162164). While voice within the existing rules can be opposed to exit in terms of abandoning the existing rules or organization, voice against the existing rules cannot clearly be opposed to exit, because in this case the frontiers between voice and exit become blurred. In other words, voice within the existing rules comes within the scope of Hirschman's dichotomy of voice versus exit, whereas voice against the existing rules escapes this dichotomy and cannot be opposed to exit.

Voice against the existing rules requires that actors also take a particular kind of exit, e.g., not remaining among loyalists and joining the opposition or the opponents. But this exit is not synonymous with emigration, because it implies active participation to overthrow the existing order. It is not a reform within the existing rules, but a revolution against them to introduce new rules causing institutional innovation. This explains why Hirschman has never distinguished between these two different meanings of voice; such a clarification would have undermined his theoretical framework in terms of the dichotomy between voice and exit.

In our opinion, a third category should be added to Hirschman's $(1970,1974)$ dichotomy of 'voice' versus 'exit' - 'scream,' which is defined as voice against the existing rules. Revolution (in all its violent and non-violent types such as the Velvet Revolutions in ex-socialist countries) is a form of 'scream,' whereas political emigration (voting by foot) is 'exit' and political reform (like Gorbachev's reform in the 1980s) is 'voice' (Vahabi, 2004, pp. 88-97). The use of 'scream' for institutional innovation could sometimes improve economic efficiency when discontent cannot be voiced. On the other hand, 'scream' can be avoided if 'voice' becomes possible. Leslie 
Stephen, the critic, essayist, and an advocate of reform in England had persuasively argued that, once in parliament, that is, "out in the open", the workers' representatives would become domesticated and even divided. Put differently, the vote delegitimizes more direct, intense, and "expressive forms of political action that are both more effective and more satisfying." (Hirschman, 1982, p. 117).

To sum up, Hirschman's concept of voice is not directly about revolution as a particular kind of conflict, but conflict within the existing rules in general. He insists upon conflict as a corrective or positive mechanism under certain circumstances notably when exit is not efficacious. In this way, he relates conflict to rule enforcement or institutional change. But does institutional change is necessarily mediated by 'conflict' or can it be carried out through bargaining process?

\section{Section 2. Transaction costs economics and the British Glorious Revolution}

Coase theorem (1960) underlines bargaining mechanism rather than conflict as the source of institutional change. Conflict is not excluded, but it is assumed to be effective as part of bargaining process. Credible threats or conflictual behavior ${ }^{11}$ are not real confrontations or violent clashes; they rather enhance the interests of contractual parties under the 'shadow of conflict'. Blackmailing is also considered to be a means of bargaining (Coase, 1988). This type of conflict in which conflictual parties are both adversaries and partners can be described as 'rational conflict', a conflict without pure destruction. Political Coase Theorem (PCT) as formulated by North (1990b) suggests a theoretical extension of Coase theorem to political relationships giving the pride of place to bargaining in institutional change. This bargaining is conducted by and among the elite.

According to North (1981, 1990a), while free-riding excludes masses from playing a key role in institutional change, elites having access to mechanisms of collective action are the principal instigators of institutional change. Thus, North and Weingast (1989) acknowledge the importance of elite revolutions such as the British Glorious Revolution in 'securing property rights.'

\subsection{Political Coase theorem and elite revolutions}

What is the consequence of applying the PCT to revolutions or revolutionary activity? Borrowing upon Clausewitz's (2006/1827) distinction between 'absolute' war and battle, the PCT is consistent with a type of revolution that comes within the scope of battle. A battle is a limited confrontation that can lead to a compromise among adversaries. If a revolution is used as a credible threat in an intra-elite conflict resulting in a new deal among them, then that revolution is compatible with the PCT. However, if the revolution is an 'absolute' or 'total' war against tyranny or an obsolete social order implying a war to the end, targeting the complete destruction of the enemy's military might, its political system or even its culture, then it is not compatible with the PCT.

\footnotetext{
${ }^{11}$ According to Vahabi (2012, pp. 155-58), conflict is not a single event but a process with three distinct moments: 1) conflictual interests; 2) conflictual behavior; 3) conflictual action. Conflictual behavior is about threats particularly credible threats but not real conflictual actions.
} 
In rational conflict theory ${ }^{12}$, war is regarded as part of the bargaining process to achieve peace. Accordingly, some of the advocates of rational conflict theory interpreted Clausewitz's 'total' or 'absolute' war as a war that never happens in reality (Sánchez-Pagés 2009). The only type of war that was assumed to be 'rationally conceivable' was Clausewitz's 'battle' (limited confrontation). Applying this theoretical framework to revolutions will result in a distinction between two types of revolutions: a revolution 'from below' versus an 'elite' revolution (Skocpol and Trimberger, 1977-1978), or 'color' revolutions versus 'radical' revolutions (Goldstone, 2009).

Despite their terminological differences, all these distinctions pertain to a fundamental difference between a revolution led by elites from above that is 'a revolution without revolution' (Adamson, 1980, p. 186) like the British Glorious Revolution of 1688 or the Neapolitan revolution of 1799, and a revolution involving popular masses, particularly workers and the poor on the French model. The former is compatible with a limited confrontation and the latter with a total war.

Trimberger $(1972,1977,1978)$ conceptualized the concept of 'elite revolutions' with regard to Meiji Restoration (1868) in Japan and the Ataturk Revolution (1919-23) in Turkey. These two revolutions, which marked the overthrow of a traditional regime in violent civil war, abolished the economic and social base of the old order, and created a modern nation-state committed to rapid industrialization, were unusual in two respects: (1) the revolutionary leaders were themselves members of the ruling stratum, holding high status and office in the old regime; and (2) revolutionary conflict and change were contained primarily within elite institutions and did not involve mass participation. According to Skocpol and Trimberger (1977-1978), this type of revolution was an alternative model compared to 'mass-based social revolutions from below' that has been defined by Skocpol (1976a, b, 1979) as a sudden, basic transformation of a society's political and socioeconomic (including class) structure, accompanied and in part effectuated through class upheavals from below such as French, Russian and Chinese revolutions. While we distinguish theoretically these two types of revolutions, it should not be forgotten that in practice one can transform into the other, and there is no insurmountable barrier between them.

A similar distinction between 'color' and 'radical' revolutions was suggested by Goldstone (2009). His 'radical' revolutions are the same as what Skocpol depicted as mass revolutions from below, and it can be characterized as "sudden detonations of popular energy and social change" (2009, p. 18). By contrast, 'color' revolutions can be described as elite-led 'negotiated revolutions ${ }^{13}$ with a rather 'nationalist' than class-orientation in which the change of regime is not through revolutionary activities of popular masses. They cover both recent and older examples. The recent ones began in the 1980s: the yellow revolution in the Philippines, the velvet revolution in Czechoslovakia, the orange revolution in Ukraine, the rose revolution in

\footnotetext{
${ }^{12}$ For an excellent survey of rational choice theories of revolution see Tazdait and Nessah (2008).

${ }^{13}$ Goldstone also adds to this list the Iranian constitutional revolution of 1905, the electoral rejection of the Pinochet regime in Chile in 1988, the protests that brought down the Suharto dictatorship in Indonesia in 1998, and the negotiated ending of the apartheid regime in South Africa in 1994. This is in line with Lawson's work on 'negotiated revolutions.' Some scholars have questioned whether this type of revolutions was in fact revolutions at all, or perhaps some new species of event such as "refolutions" (Ash, 1989).
} 
Georgia, the cedar revolution in Lebanon, and the tulip revolution in Kyrgyzstan. According to Goldstone (2009, p. 19): "Interestingly, the color revolutions were not the first revolutions to exhibit this behavior. The Netherlands' revolution against Spain (1566), the British Glorious Revolution of 1688, the American Revolution (1776), the Japanese Meiji Restoration of 1868, and the Chinese Republican Revolution of 1911 are usually seen as anomalous events by scholars of revolution, often treated as not truly revolutions at all because they lacked the terrorizing violence and authoritarian outcomes of more typical major revolutions."

The way Goldstone characterizes 'color revolution' is disputable. First, what has been called 'color' revolutions often goes beyond the 'elite' versus 'mass' revolutions. They may be pigeonholed as a different category blurring the frontiers of 'mass' and 'elite' revolutions. While they have often been the outcome of a 'compromise' between contending forces and may be described conciliatory and 'negotiated' revolutions, they are neither instigated by a fraction of the old ruling class nor by mass revolutions aiming at destroying the old state machinery. Second, the expression 'color' revolution often conflates different types of revolutions. For example, upheavals in Czechoslovakia and Poland were prepared from below undermining fundamental institutions of the Soviet type regimes, whereas revolutions in Ukraine and Romania were more limited in questioning renovating those institutions. Finally, 'color' revolutions specific to the Eastern European countries and its extension to other regions such as Lebanon by Goldstone needs more justification. Despite these objections, 'color' revolutions are relevant to our discussion since they lend credence to a 'negotiated' revolution.

For the advocates of the PCT, elites and not masses are driving forces of institutional change since they can resolve free-rider problem. According to North (1981, pp. 31-2) $)^{14}$, the free-rider problem may explain the stability of states throughout history: rulers are motivated to initiate institutional innovation, but collective action by masses is hindered. The stability of political regimes throughout history is thus enlightened by the impossibility of 'concerted revolutionary action' (Buchanan, 1979, p. 69). But if free-rider problem shuns masses from bringing institutional change, where does this institutional change come from? According to North et al. (2009), this can only stem from elites who can resolve collective action problem. In their theoretical framework, the transition from 'the limited access order or natural states' ${ }^{15}$ to 'open access order' is initiated by the elites and can be summarized as a change of elites' personal privileges to an impersonal intra-elite arrangement, and then to non-elite full participation (North et al. 2009, pp. 25-27). This explains why revolution is not considered as an appropriate means for institutional change unless it is used by elites to cut a deal among themselves or with the ruler. A revolution involving masses for total destruction of ruling structure is either impossible or a disaster. However, a color or 'negotiated' revolution avoiding class struggle is a salient illustration of efficacious institutional change.

\footnotetext{
${ }^{14}$ We do not ignore the evolution of North's thought since 1981, but he maintained his position on elites' role in institutional change then until his last contributions such as North et al. (2009) and North et al. (2013).

${ }^{15}$ North et al. (2009) and North et al. (2013) explain all human history by three social orders: 1) foraging order, 2) limited access order (LAO) or natural state, 3 ) open access order (OAO). The first order is based on small social groups' characteristic of hunter-gatherer societies. The limited access order is formed on the basis of personal relationships among powerful individuals. In the open access orders, although personal relationships still matter, impersonal intra-elite rights and extended impersonal rights of individuals, often called citizens, are fundamental.
} 
Exploring the impact of the 1688 Revolution on institutional change, North and Weingast (1989) attribute a central role to the intra-elite conflict and compromise. The revolution was a means of bargaining between the Crown as the power-holder on the one hand, and the wealth-holders notably the big merchants controlling the Parliament, on the other. Economic and political elites could find an arrangement so that the King could not unilaterally alter the terms of agreements and credibly commit to the intra-elite impersonal rules. Two points should not be disregarded in explaining why this 'negotiated' revolution became possible. First, the lack of a standing army: "It is clear, however, that the opposition would have been unlikely to succeed, had the English Crown, like its French or Spanish counterpart, had a standing army with which to quell the initial uprising" (North and Weingast, 1989, p. 814). The absence of a standing army should be explained in its turn by a number of wars and riots during the seventeenth century particularly the quest over the army's control by the Parliament or the King during 1641-42 that finally led to the New Model Army by the radicals (Goldstone, 2009, p. 26). Moreover, while much has been made of the Dutch invasion of November 1688, the depth of popular support for the revolution should not be underestimated. "As William prepared his fleet, vast sums of money poured into his coffers from the English merchant community and the English gentry-sums significantly larger than England's yearly intake from customs revenue." (Pincus, 1998, p. 54). Without preceding civil wars and popular support, the elite revolution of 1688 could not succeed. Masses cannot be disregarded in the preparation of the British Glorious Revolution.

Another major problem with North et al. (2009) interpretation of the British Revolution is the role of masses in the post-1688 period. While the revolution placed the power into the hands of a Parliament which represented merchants and landowners with an interest toward sale for the market, propertyless classes had not even had the right to vote. What was the driving force of democratization process in England? Why could the poor and politically disfranchised win universal suffrage? As Acemoglu and Robinson (2006) have pointed out, this process cannot be explained without considering workers' Chartist movement and the threat of mass revolution: "Beginning in 1832, the British political elites made a series of strategic concessions aimed at incorporating the previously disenfranchised into politics because the alternative was seen to be social unrest, chaos, and possibly revolution." (2006, p. 350). Here again, the role of masses cannot be assumed away in the post-1688 democratization process: they imposed the universal suffrage on the elite. North et al. (2009, pp. 26) oppose this idea by assuming that universal suffrage is also an outcome of elites' motivation to secure impersonal inter-elite rights: "When elites create greater open access to political and economic organizations for themselves, they sometimes have incentives to expand access along several different margins into the non-elite population." (Emphases are added). Once again, the problem is that "sometimes" entirely depends on the mass actions and not elites' initiative.

\subsection{The Glorious Revolution: Great Demarcation between Sovereignty and Property}

While the 1688-89 was dominantly considered an elite Revolution 'from above', the originality of Commons interpretation was to assess the institutional change stemming from such type of revolution in light of the labor interest. This explains why Commons differentiated two different types of 'private property': 1) despotism as 'private property'; 2) the labor's right of private property over its product. While North and Weingast (1989) as well as their critics such as 
Hodgson $(2017)^{16}$ have argued about the absence or presence of 'secure property rights' for wealth-holders before the revolution, Commons followed Locke in underlining the importance of the revolution with respect to property rights of the labor (on the difference between Commons and North, see Broda 2020).

Regarding the first type of property rights, Commons (1899-1900/1965, p. 356) noted that "A despotism is not a state. It is private property. Law is the criterion of a state, but the arbitrary, transient commands of a despot are not laws. It is the capriciousness of private property that evokes the state." The state was the Crown's private property before the 1688-89 Revolution, it was transformed into Sovereign power by the revolution. As he explained in Sociology: Syllabus: "Sovereignty involves three conceptions: coercion, order and right. These together constitute the state. Absolutism, despotism [is] not a true state." (Quoted by Dorfman, 1965, p. iv).

For Commons, while private property originates with the emergence of self-consciousness and scarcity, it is a social relation based on coercion ${ }^{17}$. "The theory of absolutism made the will of the sovereign the sole law of the land, and the fiction arose that custom itself was law only on the ground that 'what the King allowed he commanded.' Thus, in the rise of absolutism with the Tudors in England and Louis XIV in France we have reached the culmination of the natural evolution of private property." (Commons, 1899-1900/1965, p. 168). While 'the natural evolution of private property' has achieved its culmination before the revolution, the property rights of labor over its product had no meaning. This brought Commons to quote John Locke who "was the spokesman of a Revolution that changed England from Feudalism to Capitalism." (1934/1961, p. 51).

In his Chapter II, on "Method I. John Locke", Commons (1934/1961, Vol. 1) pointed out that Locke united Law, Economics, and Ethics in a single concept, Labor. The issue arose in his justification of the revolution of 1689. It was against the doctrine of a divine right of political power that Locke set up the "natural right of life, liberty, and property," derived from the right of labor to its own product: "Locke set forth the labor theory of value, not mainly as a foundation for economics, but mainly as a justification of a revolution that supplanted rights of sovereigns by rights of property." (Ibid, p. 52).

The same was true of Locke's idea of the 'sanctity of property'. For him, the rights of labor to its own product was sacred and not the private property rights in general. However, Commons

\footnotetext{
${ }^{16}$ North and Weingast (1989) identify the major institutional changes of the Glorious Revolution in terms of 'secure property rights.' Adopting a legal institutionalist approach, Hodgson criticizes their thesis for not distinguishing the 'feudal property rights' from the 'absence of property rights' in general. He writes: "Property rights in England were relatively secure from the $13^{\text {th }}$ century. A major developmental problem was not the security of rights but their feudal nature, including widespread 'entails' and 'strict settlements."' (2017, p. 79). In this debate, the major controversial issue is whether secure property rights existed before 1688-1689 or not. Hodgson argues that it did, but North and Weingast build upon the absence of such rights. However, both arguments favor secure property rights for wealth-holders and not the labor.

${ }^{17}$ According to Commons, coercion is not force. "It holds force in reserve, and, in so far as actual force is necessary, the aim of coercion (i. e., the services of the coerced) is defeated. Neither is it conquest. Conquest is only the physical exercise of force which precedes coercion. Coercion, again, is not knowledge nor skill. Man overcomes nature, not by coercing her, but by "obeying her." (Commons, 1899-1900/1965, p.155).
} 
acknowledged the changing nature of property rights that had nothing eternally sacred: "The meaning of property has greatly changed from the time when Locke personified the customs of the frugal, laborious farmers, the master mechanics, and the merchants, as a divine command of unchanging nature and reason, to the time when property is absentee control over laborers and customers throughout the world by a legalized credit and corporate system of management and a world-scarcity of opportunities. Locke's appeal to heaven was his justification of the Revolution of 1689 against the divine right of Kings over the subjects. The Philadelphia manufacturers' appeal to heaven in 1922 is their justification of a divine right of property owners over their employees." (Commons, Ibid, p. 51). For this recent period, Commons (1899-1900/1965) insisted on 'the right of employment' as a 'property right of the worker.'

The 1688 revolution was the end of despotism as 'private property', and the establishment of the sovereignty on the one hand, and the declaration of the sanctity of property rights of labor on the other. These two institutional changes were inseparable, since "it was not until the revolution of 1688 that subordinate classes achieved a recognized permanent right of participation in shaping the royal will. Sovereignty is a daily flow of coercion, and not the mere promise of a King to do and not to do so and so. Sovereignty, therefore, requires definite enduring constitutional organs for its daily exercise. Magna Charta did not adequately provide these." (Commons, 18991900/1965, p. 357).

A parallel can be made with the French revolution regarding the great demarcation between 'property' and 'sovereignty' as suggested by Blaufarb (2016). The revolution abolished privately owned forms of power, such as feudalism, seigneurialism, and venal public office, and dismantled the Crown domain, thus making the state purely sovereign. On the other hand, property was defined by rules specific to itself, not by extraneous political factors. This, in short, confirmed the autonomy of the sphere of property.

\section{Section 3. Revolutionary processes: de-institutionalization and re-institutionalization}

Until 1789 in Europe, the idea of radical change to create a new society was frightening. All changes had to be justified in the name of rehabilitation of 'traditions', traditional wisdom of the Bible, classical texts of Greek and Rome. Hence even the leaders of the Netherlands Revolution and British civil wars, and the 1688-89 revolution appealed to tradition and the defense of ancient 'laws' and 'liberties.' "It is only with the French Revolution of 1789 that we find "revolution" taking on a new meaning, as a radical attack on all older institutions in the name of creating a wholly new and better society." (Goldstone, 1998, p. xxxii). Thus, mass Revolution is an invention of modernity. Novelty, particularly major organizational and institutional innovations, is one of its constant features.

In this section, we first explore the singularity of this modern form of revolution, and then compare different patterns of institutional innovation in mass and elite revolutions.

\subsection{Specific characteristics of mass revolutions}

Three specific characteristics of mass revolutions are as follows. 
1) The first one is that they "attack on all older institutions". A mass revolution is not just a populist movement mobilized by fascists to save 'order' (army, bureaucracy, church and Fuhrer). Mass revolutions challenge the power of church and more or less destroy the bureaucratic and military apparatuses of the state. Revolution in its modern sense means the political awakening of masses by and large, and their self-government. Unless anarchy is understood as chaos and mayhem, it can be conceived of a society without a state but not without rules (Hirshleifer, 1995). This self-government is based on new forms of direct democracy or popular power in which executive and legislative powers are not separated. The communes in French revolutions of 1789 and 1871, the Soviets in the Russian Revolutions of 1905, 1917 and German Revolution of 1918; the workers' committees and commissions in the Spanish civil war 1936-1938 provide some illustrations of this new type of power. Although these new forms of power were either crushed by the old regime or degenerated later into centralized bureaucratic states (Furet, 1980/2006; Goldstone, 2009; Brown, 2015), they originated new institutions such as a national revolutionary army of citizens/soldiers, modern bureaucratic administration, and national sovereignty (Jones, 2006). Moreover, they all ushered in a new era of mass politics, invention of tradition, non-governmental mass associations, free press, and political parties (Hobsbawm, 1994; Hobsbawm and Terence, 1988).

2) Mass revolutions contain a substantial class-based component in their anti-regime oppositional efforts. Their target is not only national liberation from colonialism, national unification or liberty from tyranny, but also the elimination of privileges and socio-economic inequalities between the poor and the rich. Concretely speaking, this class orientation had at least two major implications: (i) A peasant revolution such as France during 1790-1792: using violence to destroy feudalism in the countryside by expropriating aristocratic landlords and distributing their land without indemnification among peasants (Markoff, 2006; Plack, 2015). (ii) Redistributive policies in favor of the poor, as for example the Directoire decisions in support of sans culottes during the French revolutionary wars, or the 1871 Paris Commune's initiatives for la sociale (Vahabi, Batifoulier and Da Silva, 2020).

3) Mass revolutions follow an intensifying pattern of polarization between the 'moderate' and 'radical' oppositional groups after the regime change. This is often described as a 'permanent revolution' in which the anti-regime phase (national or democratic) is followed by further polarization towards a class-oriented revolution aiming at destroying or redistributing the assets of an entire class or ruling group.

\subsection{Patterns of institutional innovation in elite and mass revolutions}

The patterns of institutional innovation are radically different in elite and mass revolutions. In an elite revolution, old institutional forms are maintained while new content is gradually added to them. The rupture between the old and new institutions are hardly perceptible, and the institutional innovation is incrementally carried out so that an institutional vacuum is shunned. In this type of revolution, the institutional innovation is like Schumpeterian technological change in which there is no leaps but a continuous process of coevolution of de-institutionalization and reinstitutionalization. In this sense, an elite revolution is a 'revolution without a revolution'. Its specific feature is the participation of a fraction of the old ruling class or group in leading the revolution. The perspicacity, flexibility, and ability of this fraction of dominant group to compromise at the right time (not too late, i.e. before the outburst of popular actions) with the 
new rising classes and groups is the key to avoid mass revolutions. The revolution is 'negotiated' from above and the leadership is partly secured by at least a part of previous ruling classes. An elite revolution is a 'voice' that eschews the outburst of 'scream', but it strongly hinges upon the leading qualities of the old ruling group and class. The British aristocracy in 1688 was particularly capable of avoiding 'scream' by playing the role of mediator in preparing the ascendancy of the British bourgeois class. The French aristocracy lacked these qualities, and the 1789 was the outcome of 'scream' instead of 'voice'.

A mass revolution marks a qualitative leap and ushers in a period of institutional vacuum. The de-institutionalization precedes re-institutionalization. Mass revolutions are marked by active involvement of masses in politics, and the emergence of a multitude of grass root organizations. However, elites are not absent in mass revolutions. They play a key role in organizing and leading the revolution. In fact, the indeterminacy of leadership is the major issue of mass revolutions in contrast to elite revolutions. A mass revolution like the 1979 Iranian revolution may result in establishing a theocratic Shiite state (Velayat faqih) due to the hegemony of traditional Shiite clergy ${ }^{18}$. The indeterminacy of mass revolutions is much higher than elite revolutions since it involves masses at a large scale. Mass revolutions are organic or 'spontaneous'; they are not invented by conspirators, political parties, or even particular classes. There are specific political and economic conditions that result in a 'revolutionary situation.' What, generally speaking, are the symptoms of a revolutionary situation? Lenin provides a comprehensive response to this question:

"We shall certainly not be mistaken if we indicate the following three major symptoms: (1) when it is impossible for the ruling classes to maintain their rule without any change; when there is a crisis, in one form or another, among the 'upper classes', a crisis in the policy of the ruling class, leading to a fissure through which the discontent and indignation of the oppressed classes burst forth. For a revolution to take place, it is usually insufficient for 'the lower classes not to want' to live in the old way; it is also necessary that 'the upper classes should be unable' to live in the old way; (2) when the suffering and want of the oppressed classes have grown more acute than usual; (3) when, as a consequence of the above causes, there is a considerable increase in the activity of the masses, who uncomplainingly allow themselves to be robbed in 'peace time', but, in turbulent times, are drawn both by all the circumstances of the crisis and by the 'upper classes' themselves into independent historical action. Without these objective changes, which are independent of the will, not only of individual groups and parties but even of individual classes, a revolution, as a general rule, is impossible. The totality of all these objective changes is called a revolutionary situation." (Lenin, 1915/1974, pp. 212-213).

A mass revolution emerges organically on the basis of a rejection platform unanimously accepted by all the opposing forces ${ }^{19}$. This organic process evolves endogenously in a similar way as a Veblenian 'selective adaptation' (Veblen1899/1994) including three elements: variation, inheritance and selection of the fittest ${ }^{20}$. In this case, 1) the 'unity phase' starts with the

\footnotetext{
${ }^{18}$ The 1979 Iranian revolution cannot be completely pigeonholed as mass revolution, since despite its attack against the Shah regime, it adopted a retrograde position toward the church since September 1979.

${ }^{19}$ This assumes the resolution of collective action dilemma. This point will be discussed below.

${ }^{20}$ Veblen was inspired by Darwin's evolutionary approach in underlining variation, inheritance and selection of the fittest. However, he modified Darwin's 'natural selection' to institutional change.
} 
de-institutionalization process; 2) the variation or differentiation phase entails 'polarization' among 'moderate' and 'revolutionary' forces and their survival struggle; 3 ) the selection of the fittest or 'domination' phase during which new institutions are born. The 'fittest' social groups are selected according to their politico-military capabilities and not necessarily their economic efficiency. The revolutionary forces might be economically unsupported by social groups that have economic power but lack the politico-military forces. The new institutions generated as a result of survival struggle of the 'fittest' might be economically inefficient, but in the long term their survival requires economic support. Herein lies the fourth phase of the evolution: reinstitutionalization phase or 'restoration' during which a compromise is sought between the two groups of politico-military and economically fittest social groups to secure a sustainable political and economic order.

After presenting our theoretical framework of mass revolutions, we explain the four phases of de-institutionalization and re-institutionalization processes.

\section{1) Unity phase or de-institutionalization process}

The whole revolutionary process starts by a first phase of rejection or 'unity' against the political regime or the tyrant in the pre-revolutionary period, and it ends by a regime change. This is a period of convergence, unity, or tacit coordination among different oppositional forces against the common enemy. The enemy represents all the vices and the opposition all the virtues: a Manichean war of good against evil. This phase of universal brotherhood can be defined as a deinstitutionalization process. All the past institutions reach a state of standstill or collapse. They no longer regulate and coordinate social relationships. The new rules are burgeoning but not strong enough to rule or govern activities. An institutional vacuum prevails.

Vahabi (2004, p. 140) provides a solution to the problem of collective action dilemma in mass revolutions by referring to destructive activity: "In analyzing the collective choice of using destructive power (revolution is a salient form of such power), one should pay attention to the difference between a negative and a positive action...It is always easier to say what we do not want than what we want...In terms of costs and benefits, one may say that the cost of rejection agenda is ambiguity in choice, and its benefit is fewer constraints. Costs and benefits will be reversed in the case of a positive agenda...It is easier to be united on a rejection agenda than on a positive one." In other words, collective action dilemma is relevant in case of 'positive agenda' but not for a 'rejection or negative agenda'. There are two major advantages to a rejection agenda: (I) rejection of the existing order as a collective rational choice without violating democratic procedures; (II) higher marginal pay off of destructive activity to productive effort among the poorer side of a conflict. We start by the first advantage.

(I) Rejection of the existing order as a collective rational choice in conformity with democratic procedure: Borrowing upon Arrow's impossibility theorem ${ }^{21}$, a rejection agenda means that the

\footnotetext{
${ }^{21}$ Arrow's Impossibility theorem states that if there are at least three social outcomes, then no social choice rule simultaneously satisfies four properties as follow. "Property 1. The social choice rule should prescribe an asymmetric and negatively transitive ordering $>*$ over social outcomes $\mathrm{X}$ for every array of individual preferences
} 
third property of Arrow's theorem, that is the assumption of 'independence of irrelevant alternatives' (see Kreps, 1990, p. 177) can be relaxed. This is consistent with the fact that a mass revolution starts with a deep popular dissatisfaction or rejection of the existing regime. This rejection is so intensely desired and preferred by the majority of active population that it dominates all other alternatives. Thus, the outbreak of a revolution as a collective action does not need to relax any other assumptions including 'democratic procedure' (Property 4).

The formation of a collective rational choice to reject the existing regime on a democratic basis means that institutions that have been accepted previously as 'prevalent habits of thought and character' (Veblen1899/1994, pp. 118-119) no longer have sufficient power to be enforced and govern collective actions. An institutional vacuum ensues in which people perceives themselves as the legitimate sovereign power to define new institutions rather than the rejected ruling power.

(II) Higher marginal pay off of destructive activity to productive effort among the poorer side: As discussed in Vahabi (2010), this is an upshot of Hirshliefer's (1991) 'Paradox of Power' (POP): "What is coined as 'paradox of power' (Hirshleifer, 1991) is the observation that... poorer or weaker contenders improve their position relative to richer or stronger contenders. The theoretical basis for this contention is that the initially weaker or poorer contestants are typically motivated to fight harder, that is, to devote relatively more effort to appropriative (conflictual) effort. In other words, the marginal payoff of appropriative activity to productive effort is typically greater among those with low income." (Vahabi, 2010, p. 695). This provides an economic motivation for revolutionary masses to organize in fighting activities such as strike committees, street demonstrations, fighting squads or even revolutionary armies.

Mass revolutions are more class-oriented, and this entails better material opportunities for propertyless classes to organize themselves as a fighting force. However, this is the source of a major contradiction in mass revolutions, namely the discrepancy between military and political conquest of the power by propertyless classes on the one hand, and the insufficiency of economic conditions (including the managerial and intellectual force to organize the new order) for their rule, on the other. Herein lies the interaction between politically and military powerful propertyless classes with economically powerful wealth-holders lacking political and military power. The allegedly opposite stages of 'polarization' (revolutionary terror) and 'moderation' (after the fall of Robespierre) in revolutionary processes might be explained by the abovementioned fundamental contradiction of mass revolutions and the interaction between propertyless powerholders and property-holders with a dearth of power.

Empirical evidence concerning this initial phase can be found in Goldstone (2009). According to the author's extensive case studies of different revolutions in the past and present, both type of 'color' (elite) and 'radical' (mass) revolutions include twelve components that constitute revolutionary processes. These are: 1) Elite defection and the formation of opposition; 2) polarization and coalition building; 3) mass mobilization; 4) initial regime change; 5) further

$\left(>_{\mathrm{i}}\right)$...Property 2. Pareto efficiency. If $\mathrm{x}>_{\mathrm{i}} \mathrm{x}$ ' for all $\mathrm{I}$, then $\mathrm{x}>^{*} \mathrm{x}$ '...Property 3. Independence of irrelevant alternatives...Property 4. Absence of a dictator.” (Kreps, 1990, pp. 176-177). 
polarization; 6) civil war; 8) international war; 9) radical regime change and "terror"; 10) revolutionary moderation; 11) renewed radicalism and "terror"; and 12) regime consolidation.

Our "unity or de-institutionalization process" represents analytically what Goldstone (2009, p. 20) empirically describes in stages 1, 2, 3, and 4: "In most historical cases of revolution, stages 1 , 2, and 3 form a "suite" of changes that develop before the overthrow of the old regime, with all three going on at the same time and reinforcing one another. However, the intensity and character of these conditions can vary considerably... These lead up to stage 4, the initial regime change. Usually, the initial regime change occurs before all the tensions and contradictions in the opposition coalition have been resolved."

\section{2) Polarization phase}

The second phase starts immediately after the regime change. This is a 'variation' process in which different opposition tendencies such as 'moderates' and 'radicals' differentiate and oppose each other on many issues like property rights, form and type of political power, etc. Polarization happens in every type of revolution, but mass revolutions are particularly marked by intense political rivalry among 'moderates' and 'radicals' regarding the class-orientation of revolution. Multiple equilibria or different solutions to revolutionary crisis are possible. Moreover, the relative importance and influence of different political tendencies are transitory and changing rapidly; a stable equilibrium is still to emerge. Specific historical events, particularly military putsch, inter-state or civil wars can have consequential effects on the radicalization of the revolutionary process in this stage. This is what we named indeterminacy and multiple equilibria. The historical events or 'small changes' in favor of this or that political tendency can change the balance of power between 'moderates' and 'radicals.' For both elite and mass revolutions, this second phase is characterized by intense rivalry or 'survival struggle' among political parties rather than unity to achieve the hegemony. Politics is no more a 'pure' public good for everybody (non-excludable and non-rivalrous) but rather a 'club' good (excludable for nonmembers or non-partisans). In this phase power networks constitute and multiply, but the institutionalization is not yet started, since none of the political tendencies is hegemonic in the opposition. Institutionalization requires domination or 'selective adaptation'. This period might be empirically illustrated by what are included in Goldstone's (2009) stages 5, 6, 7, and 8. "Then stages 5-9 form another suite of connected events, as these stages often occur together or in tight sequence as a cluster of events, again mutually reinforcing one another. Only when radicalism, counterrevolution, and civil war and international wars have ended has the revolution reached a stage of moderation and stability. Even that stage is not the end, however, as many revolutions experience a further stage of renewed radicalism." (Goldstone, p. 20).

\section{3) Domination phase: the emergence of new institutions}

The specific historical events (such as revolutionary wars and civil wars) during polarization stage may lead to further polarization, and set in motion a dynamic that in Marxist literature has been coined 'permanent revolution'. The pursuit of the initial revolution over a general agenda (democratic or national) by a 'second' (egalitarian or socialist) revolution is the pattern of mass revolutions as seen in Russian, Chinese, Vietnamese, and Cuban revolutions. This entails a further polarization among 'moderates' and 'radicals', and sometimes a regime of terror not only 
against the protagonists of the old regime but also within the revolutionaries: "Like Saturn, the revolutions devour its children" (Mallet du Pan, 1798/2009). The survival of the 'fittest' in terms of politico-military qualities determine the emergence and type of new institutions. The empirical evidence in Goldstone's (2009) stage 9 casts light on this phase.

In this phase, it is particularly important to explore whether the radical political force and propertyless social groups that have benefited from the revolutionary crisis to come to power and win political and military domination have strong economic base or not. In other words, a major question is whether the economic situation is sufficiently ripe to implement redistribution policies of the radical governing parties. The incompatibility between the 'military' or 'political' victory on the one hand, and the lack of 'economic' means, on the other hand, results in using brutal force by the new ruling party to compensate for economic situation. This dependence on brutal force and authoritarian methods often leads to the institutionalization of war (internal class wars or/and external revolutionary wars) that originates a 'permanent war economy'. The dependence of the Directoire on revolutionary wars in the French Revolution provided the first illustration of such an economy ${ }^{22}$. The same story has been reproduced at a larger scale in the aftermath of the First and the Second World Wars in the case of Soviet type economies. As Lange (1958, p. 3) clearly formulated, socialism can be described as a sui-generis war economy.

\section{4) Restoration or re-institutionalization}

This final phase that usually arises after the terror period in mass revolutions consolidates new institutions. The brutal force and expropriation are not sufficient to establish an egalitarian society $^{23}$. The radical parties are often either removed by a putsch or transformed gradually into a 'moderate' party. The process of gentrification (embourgeoisement) opens the door to moderation, partially revivifying the previous privileges of wealth-holders and powerholder classes. This phase is echoed in empirical evidence of Goldstone (2009, p. 20) regarding stage 12: "only when that fire [renewed radicalism] burns out does the revolution settle down into a conservative or stable consolidation, in which the main goals of the regime are simply to prosper and remain in power." (Terms in brackets are added).

The interaction between politico-military and economic power determines the reinstitutionalization of an emerging order as a constellation of 'new' and 'old' institutions. Variation, inheritance, and survival struggle drive adaptive selection of new institutions. Paradoxically, in this constellation some newly created institutions contain old contents, and some old remaining institutions gradually encapsulate new contents. However, in general, the restoration is not the reproduction of the past but the adoption of a new social order borrowing traditional forms.

\section{Section 4. The French revolution: an archetype of the mass revolution}

\footnotetext{
${ }^{22}$ This point will be further discussed in next section.

${ }^{23}$ This does not mean that we deny the historical role of violence as 'great leveler' (Scheidel, 2017) but it cannot build an egalitarian society.
} 
The French Revolution of 1789 has been the subject of many interpretations. A common approach, sometimes called "orthodox" (McPhee, 2013a) describes it as a revolution of the bourgeoisie against feudalism to develop capitalism. The Marxist version puts forward the class struggle (Soboul, 2006), while a "revisionist" interpretation following Furet (1978) insists on the political conflict among different fractions of the bourgeoisie. Despite their divergences, all these interpretations converge on the role of the masses in the revolutionary movement. The French revolution was the first radical and total social revolution in one of the most powerful countries of the time. It has become a focal point of the revolutionary act in the history of nations.

\section{First Phase: de-institutionalization (1789)}

In 1789, the situation in France was revolutionary in the sense defined in section 3. The working classes suffered more than usual because of a succession of bad harvests, but also of the taxes decided by the King to finance the American revolutionary war (Labrousse, 1990). The "subsistence crisis" resulted in multiple revolts in a context where a considerable part of the economic and political elite of the country challenged the feudal order. As an ascending class, the bourgeoisie wanted to conquer the share of political power corresponding to its economic importance as summarized by the lawyer Antoine Barnave: "a new distribution of wealth prepares for a new distribution of power" (Barnave, 1843/1988, p. 52). For the bourgeoisie, a change in political power could make it possible to impose on the clergy and the nobility a part of the tax (from which they were previously excluded), and to implement economic reforms favoring the market economy detrimental to the feudal economy. Other groups within the aristocracy wanted a reform of feudal institutions, such as the lower clergy, close to the people or the nobility sensitive to liberal ideas. The Estates General were convened at the request of the feudal lords who refused to pay the tax and contested the absolutism of the King.

If the situation was revolutionary, the French revolution could not be an elite revolution similar to Britain. Albert Soboul clearly depicts the attachment of the aristocracy to the feudal order: "At a time of social and institutional crisis, the years preceding 1789 saw the unfolding of a serious political crisis, motivated by the financial powerlessness of the monarchy and its inability to reform: each time a reforming minister wanted to reform the state, the aristocracy stood up to defend its privileges" (1982, p. 117). The French aristocracy was distinguished by its constant refusal to compromise with the bourgeoisie.

However, the abolition of privileges was not only the product of the revolutionary emulation of representatives drawn from the bourgeoisie. As McPhee (2013a) points out, at the time of the convocation of the Estates General, the deputies did not think about the revolution. It was the peasant revolts that catalyzed the struggle. The French revolution was not only in the cities, and particularly by Parisians. It was also in the countryside where rural violence was expressed against the lords. By demanding food and drink, the insurgents also attacked seigneurial symbols as shown by Markoff (2006, p 247) in his long list of violence in the countryside

The violence was directed against feudal institutions. It expressed a fight against the existing rules falling under the "scream" rather than the "voice". The peasants' collective engagement in the revolution was very broad when they could lose. The issue of the free riding and the classic 
problem of collective action that would condemn any mass revolution was lifted by a common belief in the value of a successful revolution (Olsson-Yaouzis, 2012). This peasant violence galvanized the legislator at the same time as revolutionary measures fueled peasant revolts to lead to the destruction of feudal institutions.

The de-institutionalization was also the product of the rejection of any compromise by the aristocracy.

The nobility refused the third state, representing the vast majority of the population ${ }^{24}$, the vote by head after the convocation of the Estates General in 1788. Voting by order (each order discussed in a separate chamber and voted as one body separately from others) was to the advantage of the privileged majority (nobility and clergy against third estate), and thus in support of the status quo. That was the beginning of the disobedience of the representatives of the third estate against the King, who gradually succeeded in proclaiming the National Constituent Assembly with the help of some deputies of privileged orders on July 9, 1789. When the King decided to resort to force to punish the actions of the third state, the latter called for the constitution of a Parisian militia (composed exclusively of elements of the bourgeoisie ${ }^{25}$ ), but it also appealed to the popular classes aspiring just as much as the end of the Ancien Régime.

The Assembly abolished feudal privileges on the night of August 4. Although largely formal, this abolition led to the legal destruction of the Ancien Régime: end of privileges, particularisms, an equal footing in taxing. The declaration of human rights of August 26 launch the legal reconstruction of society by promoting both the concept of freedom and equality.

These initial events clearly showed a mechanism that was at work permanently during the revolutionary period: faced with an aristocracy incapable of compromise, the bourgeoisie was forced to rely on the urban and rural working classes around a common agenda defined negatively: the end of the Ancien Régime. The double condition of the negative agenda (section 3.2) was regularly met: a) a tacit agreement on political and economic priority: finish first with the aristocracy (not necessarily the King), that is to say with feudal rights and the society of order; b) a hope of greater gain through destructive activity than through production. In the situation of subsistence and financial crisis of 1789 , both for the working classes and for the bourgeoisie, the hope of gaining from overthrowing (or radically reforming) the regime was superior to productive activity (keeping the status quo).

\section{Second phase: polarization (1790-1793)}

After the events of July 1789, except for a minority close to the bourgeoisie, the aristocracy spent its time preparing for the counter-revolution. The third estate, was divided because of the opposition to the positive agenda for rebuilding society. The ambivalence of the concepts of

\footnotetext{
${ }^{24}$ Soboul (1982) estimates the number of the nobility at 350,000, those of the clergy at 120,000 and those of the third estate at 26 million. If the three orders are made up of a heterogeneous population, it is in the third estate that heterogeneity is strongest: bourgeois (commercial, financial, manufacturing, of the Robe, liberal professions, shopkeepers and artisans), urban popular class (dependent crafts, laborers, companions, apprentices, day laborers), peasantry (serfs, free peasants, farmers, plowmen, sharecroppers). The peasantry represented about $75 \%$ of the total population in 1789 .

${ }^{25}$ This social composition of the militia can partly be explained by the high costs of weapons.
} 
freedom and equality gave way to contradictory alternative futures. The construction of a positive agenda ran up against different positions regarding the levels of democratization and economic liberalism. This is why the Revolution remained very unstable. If the bourgeois majority sought common ground with the aristocracy, the latter refused to accept a compromise. This situation explained the failure of the 1791 Constitution and the path to the radicalization of Year II.

The moderate called "Girondins" were dominant in the assembly. To avoid the counterrevolution, they engaged in compromising with the nobility as illustrated by the Constitution of September 3, 1791 (Tackett, 2006). Although the King's power was subordinated to the wishes of the elected officials, the King led diplomacy (without the right to declare war), and had a suspensive veto. On the aristocratic side, following the abolition of privileges the dominant feudal rights were abolished without compensation (right of justice, mortmain, serfdom, corvée, toll right, market, hunting and fishing rights taxes, etc.). But the feudal contracting party rights were declared redeemable (cens, champarts, annual fee, etc.). The purchase price was so high, that the aristocracy's economic dominance over the peasantry remained massive. Clergy was worst affected because the tithe was suppressed, and its property was partly sold to finance the state debt (this was the origin of the creation of the assignats). Nevertheless, the law of July 12, 1790 instituted the civil constitution of the clergy that created a legal space for religion within the state (unrelated to the coming dechristianization). The constitution granted suffrage only to the wealthy (bourgeois or aristocrats) and ranked citizens according to their ability to pay for having access to political rights: passive citizens, active citizens, electors, and deputies.

Thus, the bourgeoisie did not attack primarily the economic resources of the aristocracy, but its political prerogatives. This explains why it could enforce its economic liberalism: laissez-faire, laissez-passer. The bourgeoisie intended to impose its conception of property. This led to a whole series of reforms: freedom of culture, freedom of production (destruction of corporations; Allarde's decree of March 1791), freedom of work (prohibition of coalitions to increase the price of labor; Le Chapelier law of June 1791 to ban corporations), freedom of trade (free movement within the national territory as well as for export, of grains and other goods by abolition of customs and dissolution of commercial companies), freedom of banking and financial activities.

These measures were carried mainly by "La Gironde" which was opposed to "La Montagne", considering itself as the spokesman of the masses. The bourgeoisie as a whole had some common interests. The democratization of society was limited by the right of property. The constitution of 1791 only granted the active citizen status to those who could buy it, thereby removing those from power who could jeopardize property. The Montagnards were favorable to political equality in order to defeat the counter-revolution, but economically they advocated property against the sans-culottes and the clubs like the enragés and cordeliers (Jessenne, 2012; Hermann-Mascard, 1991; Margairaz, 1991).

However, the value of the assignat fell steadily, the tax revenues were insufficient, and the subsistence crisis deepened, fueling the discontent of the popular classes. They also began to suffer from the removal of Ancien Régime protection in the new laissez-faire paradigm. 
The situation was also dramatic politically since the vast majority of the aristocracy refused the Revolution. Since July 1789, many nobles emigrated and organized the struggle against the new social order by relying on European monarchies to restore the Ancien Régime (Pillnitz declaration, Brunswick manifesto, etc.). The King showed great unwillingness to validate the laws and even organized his flight in June 1791. While the people lost confidence in the King, the Girondins' policy protected him and supported the aristocracy against the aspirations of the masses. They backed the shooting of the field of March on July 17, 1791, when the popular classes manifested their will to sanction the King following his failed flight from Varennes.

The War started on April 20, 1792 with a series of military defeats. The French army was particularly disorganized due to the emigration of many noble officers. The Assembly proclaimed the 'fatherland in danger' on July 11, 1792; the Brunswick manifesto was known in Paris on August 1. In this context of imminent danger for the revolution and fear of the "aristocratic conspiracy", the masses of the people again entered the scene and jostled the Girondins' agenda: the enlargement of the National Guard to passive citizens, the establishment of the Paris Insurrectional Commune (composed of sans-culottes), and the foundation of universal suffrage for electing the Convention.

The Girondins' policy could only be maintained as long as military successes accumulated. However, from March 1793 it was the defeats that accumulated, thereby reinforcing the economic and political crisis which had not yet found an answer. The crisis strengthened the advocates of the radical fraction of the bourgeoisie (the Montagnards). Between betrayals (like that of General Dumouriez) and the uprising in Vendée, the policy of compromise was a failure leading to the Montagnard power.

The events led the Convention to adopt the solutions of a command economy and terror supported by the Montagne: revolutionary tribunal, surveillance committees, repression against the emigrants, committee of public safety, forced course of the assignat, departmental maximum of grains and flour, forced loan from the rich. These decisions were fought by the Girondins, now in the minority, who cried out against dictatorship, but supported by a popular insurrection of the Parisian sans-culottes (mainly on May 31 and June 2). The Montagnards arrested the Girondins deputies for being guilty of leniency towards the monarchy. The attempt to establish a compromise between aristocracy and bourgeoisie failed.

\section{Third phase: hegemony (1793-1794)}

With the advent of the Montagne Convention, the French Revolution entered in its hegemonic phase or permanent revolution. The Montagnard objectives were to win the war against the European monarchies, and to destroy the internal counter-revolution. Unlike the Girondins, they did not want to compromise with the aristocracy, and were ready to completely liquidate the masters of the Ancien Régime. Like the Girondins, the Montagnards defended the interests of the bourgeoisie, and refused to completely adhere to the popular aspirations. They refused the sansculottes proposals, in particular with regard to property and democracy. Mass revolution involves an active participation of the masses, but they do not lead the revolution day by day. 
The period of hegemony of the Montagne during the revolution can be summed up in three logically articulated pillars: citizen warfare, command economy and terror. With the threatening counter-revolution, the Montagne invented the citizen warfare in the sense that war was waged by citizens defending their economic and political freedoms. Military and civic victory then presupposed a high level of control over economic activity, the refusal of which by the rich was sanctioned by terror. The collapse of a single pillar would imply the end of this hegemony.

In order to save the revolution and win the war, the Montagne had to radicalize the democratization of society, in particular by opening the army to citizens. With "levée en masse", every Frenchman became a soldier. Conscription was an illustration of the deinstitutionalization of the previous military organization, and military power (Blanning, 1986). It paved the way for the democratization of the army and for meritocratic promotion, as the case of Bonaparte demonstrated. The revolution completely crushed the feudal army, and replaced it by a national army. The number of soldiers increased to one million men, made up of both volunteers and those drawn from levée en masse. The cadres were gradually replaced, and the principle of electing commanding officers (as in the National Guard) was instituted on February 21, 1793 (only the generals were appointed by the executive).

The citizen army was national and democratic: soldiers were invited to attend clubs and read the press. The soldier-citizen did not fight a particular enemy, but fought for the end of privileges. Viewed by Robespierre as "the people's war against tyranny, and not that of the Court" (cited by Leuvers, 2014, p 220), citizen warfare gradually became a mean for unifying the people (Belissa, 2012) by presenting itself as a war against privileges to terminate feudalism (Forest, 2002, Markoff, 2006). To protect the revolution against "the party of the foreigner", the soldier had to become a citizen but the citizen soldier had to benefit from the advantages of the nation. The target of the "Patriotic assistance" was the combatant. The scarcer the resources, the more the regime favored combatants (and veterans), and their dependents such as war widows (Brown, 2013).

The social support for citizen war was explained by the deepening of the political and economic rights of the masses, both based on the command economy. For mobilizing the army and winning the victories, it was necessary to resolve the arming and supply issues. Command economy could secure the material existence of the army, and satisfy certain popular aspirations (Woronoff, 1991). The laws regarding requisitions, price control, nationalization, etc. were all closely related to the war requirements. By taking control of the state apparatus, the Montagne bourgeoisie enacted the "maximum" law in 1793 which imposed a maximum price for grain in each department. Fixing administrative prices for foodstuffs was accompanied by the regulation of the firewood trade, and even requisitions (Woronoff, 1991). Social regulations were, however, subordinated to the liberalization of the economy which was thwarted by exceptional events provoked by the war (Antonetti, 1991). By refusing religious charity, the revolution developed "benevolent" aid in the form of pensions for a broad spectrum of recipients (Brown, 2013).

The Constitution of Year II enshrined the access of passive citizens to the status of full citizens. It instituted direct universal suffrage, the referendum, and it strictly subordinated the action of the ministers to the national representation. The declaration of rights in the preamble was also 
more ambitious than that of 1789: the rights to work, assistance, education, insurrection and public happiness. The constitution extended rights, and gave more substance to the concepts of freedom and equality. Civil rights, like social measures, were however limited by property rights. The revolutionaries did not follow the radicalism of the sans-culottes who asked to limit drastically the property rights to redistribute wealth ${ }^{26}$.

In the mind of the Montagne, terror was the consequence of the struggle against enemies of the revolution, as well as against opponents of war economy measures (speculators, manipulators, etc.). The citizen army of the Montagne Convention accumulated successes both on the external borders, and against internal threats (Vendeans, Chouans ${ }^{27}$ ). However, the discrepancy between the political power acquired by the Montagnards / sans-culotte alliance, on the one hand, and its economic base, on the other, was too large to stabilize the political situation for revolutionaries. Terror allowed for a time to overcome contradictions but, torn apart between the Gironde and the sans-culottes, the Montagnards lost their support among both groups. This resulted the fall of Robespierre (called Thermidor's event).

\section{Fourth phase: reinstitutionalization (1794-1799)}

The end of the Montagne Convention corresponded to the beginning of the restoration phase during which the new institutions were gradually consolidated. The Girondin bourgeoisie regained power, and revitalized its concept of property, and political organization. "White terror" replaced the "Montagne terror", and the aristocracy regained strength. Still trapped between aristocracy and sans-culottes, the bourgeoisie was forced at the end of the period to switch to the military dictatorship to ensure the consolidation of the new institutions.

Switching backward was expressed in many ways: the inheritance laws of 1790 and 1793 stipulated equal footing for children regarding the inheritance, but the introduction of some sort of parental discretion precluded the advantage granted to girls (McPhee, 2013b). The dechristianization which had accelerated since 1792 was stopped: in addition to a softer approach to the refractories, and the temptation of armistice with the Chouans, the civil contract that had finished with the religious authority on the marriage was weakened. The church partially regained its influence on family matters (Desan, 2013).

At the same time, the return of economic freedom was expressed by undermining the requisitions, administrative prices and nationalizations. Trade was liberalized for both imports and exports. This contributed to the fall in the value of the assignat, and to runaway inflation which could only cause popular anger. During the winter of 1794-1795, the famine caused the last popular insurrections. But, having learned the lessons of year II, the new regime exerted a

\footnotetext{
${ }^{26}$ In a famous declaration, the sans-culottes advocated the limitation of property in these terms: "8 That the maximum amount of wealth will be fixed; $9^{\circ}$ That the same individual can only possess what is fixed as maximum; $10^{\circ}$ That no one can hold on to rent more land than what is necessary for a given quantity of plows; $11^{\circ}$ That the same citizen can only have a workshop, only a shop "(Soboul, 1982, p. 314)". The property must not be unlimited, and abuse cannot be tolerated.

27 The "vendeans" are royalist opponents to the revolution who act north of the river Loire, the "Chouans" in the south.
} 
strong repression: death penalty against the seditious, distribution of weapons for the bourgeois' militias, prohibition of carrying arms among the most radical sections, etc.

The stabilization of the regime needed a constitutional renewal. The constitution of year III legally enshrined the Republic of owners, and for this reason was a step backward compared to 1789. Article 1 of the declaration of rights was abandoned (men are born free and equal in rights). The only equality proclaimed was civil equality. Unlike the previous ones, the constitution defined precisely what property was in its limitlessness. Democracy became censal again. As wars became more clearly wars of conquest, the citizen army changed its spirit: instead of defending the revolution, the soldiers were now valuing the conquering warlord. This context favored the notoriety of generals, like Bonaparte. The 18th Brumaire of Napoleon Bonaparte ended the Revolution, and initiated the imperial period. After 10 years of Revolution, the urban and rural masses could not reap the fruits of their engagement by improving their living standards. War spread across Europe, and economic resources were diverted from other types of investment. But should one deduce that the revolution produced no positive institutional and economic impact?

The clearest positive impact of the French Revolution was the partial destruction of the aristocracy and feudal institutions. With the gradual radicalization of the revolution and the aristocracy's refusal to compromise, feudal rights were completely abolished. The state's and the clergy's assets as well as those of the emigrants were sold to finance the Revolution. If one can doubt the efficiency of the use of these funds, it is clear that the reallocation of resources and the removal of personal servitudes contributed to economic and political dynamism in the 19th century. The nobility of robe was also affected by the end of the venality of the offices. The end of feudal institutions had a major outcome: the great demarcation between Sovereignty and Property as designed by the Lyonnais magistrates: "On one side should be the sovereign state, divested of its holdings but guaranteeing the property of persons, while on the other should be society, defined by inviolable, individual property-holding. The continuity with the Night of August 4th - and the sixteenth-century jurists whose dream of demarcation informed it - is clear." (Blaufarb, 2016, p. 217).

The revolution has been exported beyond borders: Belgium, Amsterdam, right bank of the Rhine, Savoy, Nice, Catalonia, Switzerland, etc. The institutions of the French Revolution (civil code, equality before the law, questioning of aristocratic privileges, etc.) were imposed on other countries by producing positive externalities. Acemoglu et al. (2011) showed a positive link between the number of years of French occupation in Germany, and economic growth as proxied by urbanization after 1850. Contrary to the mainstream economics and partisans of elite revolutions (North et al., 2009), a mass revolution can have strong positive externalities. It was the radicalism of the French revolution that brought about the transformation of institutions in France and outside of France (Boix, 2003).

The most important outcome of the political takeover of the bourgeoisie concerns the liberalization of the economy and the application of laissez-faire, laissez-passer where the regulations of the old regime prohibited innovation in the production and circulation of wealth. This freedom was, however, a double-edged sword since the ban on corporations and workers' 
coalitions (unionism) greatly contributed to the suffering of the urban masses. More broadly, the revolution built the very possibility of an internal market. The abolition of internal customs and other rights of way contributed to the economic unification of the territory.

If in banking, there were continuities between the Ancien Regime and the revolution, the creation of the Banque de France at the beginning of 1800 characterized the desire to develop rent-seeking behavior by bankers (Rouanet, 2019). However, the central bank had the right to refuse to mint money to meet the needs of the Treasury (Plessis, 1991).

The unification of languages and the use of metric measures were part of this movement. The situation favored the modernization of the peasantry. If only a tiny fraction of poor peasants could acquire land, the sale of old regime goods and liberalization (of grain cultivation, trade, etc.) allowed the new owners to innovate and develop their properties. The advent of the Empire buried the bourgeois hopes of suffrage by census (access to the vote depends on whether or not one paid taxes). But, on the economic level, the revolution was profoundly bourgeois, since the owners' economic activity was now freed from the political and economic shackles of the old regime.

The French revolution also helped modernize the state. Among the state reforms, the end of the venality of offices was symbolic, because it epitomized the transition from a conception of state administration based on economic power to one based on merit (Pinsard and Tadjeddine, 2019). Revolutionary events led to the secularization of the state, and the separation of the state from the church. The judicial administration was modified in order to reinforce the separation of powers. Taxation were completely redesigned around the idea of tax equality (no exemption as under the old regime). It was uniformized all over the territory, and was simplified (less different contributions).

\section{Conclusion}

In this paper, we questioned a very deep-rooted bias in the economic literature with regard to conflict and revolution. Contrary to Political Coase Theorem (CPT), conflict cannot be reduced to an economic transaction. Conflict has a decisive role both in redistributing and destroying resources as well as in changing the rules or institutions. Conflict in general and revolution in particular are not necessarily 'dark side of self-interest' or bad things. They may be sources of political and economic efficiency depending on their incidence on institutional change.

Revolution escapes from Hirschman's dichotomous corrective mechanisms of 'voice' versus 'exit'. We consider it as scream exiting from existing rules and voicing new rules. Revolution is a collective action but not an institution, since it questions the established order without replacing it with a new one. It ushers in a period of institutional vacuum, but actively contributes to the creation of new institutions, notably the state and new property rights.

Two major types of revolutions, namely the elite revolution and the mass revolution need to be distinguished. The former is led by a fraction of the old elite group, while the latter is driven by social groups and classes that were previously non-dominant. The 1688 British Glorious 
Revolution and the 1789 French Revolution are two emblematic figures of these two types of revolutions.

Our theoretical framework suggests that revolutions are a source of institutional innovation characterized by a process of de-institutionalization and re-institutionalization. The Veblenian 'selective adaptation' on the basis of differentiation, inheritance and selection provides an endogenous explanation of its different stages.

Mass revolutions are particularly characterized by the polarization process on the basis of class divisions. The polarization has often led to a discrepancy between economic and political power. While masses are composed of the propertyless social groups conquering the political and military power on the one hand, the economic power is in the hand of property-owners. The reinstitutionalization process involves a consolidation phase in which economic interests reshape the ruling military and political elites' orientation.

\section{References}

Acemoglu D., Cantoni, D., Johnson S., Robinson J. [2011], The Consequences of Radical Reform: The French Revolution A Theory of Political Transitions, The American Economic Review, 101(7), 3286-3307.

Acemoglu, D., Robinson J. [2006], Economic Origins of Dictatorship and Democracy, Cambridge, Cambridge University Press.

Antonetti G. [1991], Introduction, in: Etat, finances et économie pendant la Révolution française, Paris, Comité pour l'histoire économique et financière de la France, VII-XXII.

Ash T. [1989], The Uses of Adversity: Essays on the Fate of Central Europe, Cambridge, UK: Granta Books/Penguin.

Barnave A. [1843/1988], De la Révolution et de la Constitution, Grenoble, Presses universitaires de Grenoble.

Belissa M. [2012], Robespierre et la guerre, in: Biard M., Bourdin P. (eds.), Robespierre. Portraits croisés, Paris, Armand Colin, 95-108.

Blanning T.C. [1986], The origins of the French revolutionary wars, Longman Group Limited, London and New York.

Blaufarb R. [2016], The great demarcation: the French revolution and the invention of modern property, Oxford and New York: Oxford University Press.

Boix C. [2003], Democracy and Redistribution, New York, Cambridge University Press.

Boulding K. [1962], Conflict and Defense. A General Theory, New York, Evanston and London, Harper and Row Publishers.

Broda P. [2020], "Institutions, economy and politics: the debate between Commons and North", The European Journal of the History of Economic Thought, 22 October, https://doi.org/10.1080/09672567.2020.1837197 
Brown H. [2013], The new security state, in: McPhee P. (ed.), A companion to the French Revolution, West Sussex, Blackwell Publishing Ltd., 343-358

Chavance B. [2012], John Commons's organizational theory of institutions: a discussion, Journal of Institutional Economics, 8(1), 27-47.

Clausewitz C. [2006/1827], On war. Translated by Michael Howard and Peter Paret. New York, Oxford. University Press.

Coase R. [1960], The Problem of Social Cost, Journal of Law and Economics, 3, 1-44.

Coase R. [1988], Blackmail, Virginia Law Review, 74(4), 655-676.

Commons J.R. [1899-1900/1965], A Sociological View of Sovereignty by John R. Commons [1899-1900], New York, Augustus M. Kelley, Bookseller.

Commons J.R., Wisler W., Hanke A. [1921], Industrial Government, New York, MacMillan.

Commons J.R. [1934/1961], Institutional Economics. Its Place in Political Economy, 2 vols. Madison, The University of Wisconsin Press.

Commons J.R. [1934/1964], Myself, Madison, University of Wisconsin Press.

Commons J.R. [1970], The Economics of Collective Action, Madison, Milwaukie, and London, The University of Wisconsin Press.

Desan S. [2013], The French Revolution and the Family in: McPhee P. (ed.), A companion to the French Revolution, West Sussex, Blackwell Publishing Ltd., 470-485.

Dorfman J. [1965], John R. Commons' General Theory of Institutions, in: Commons J.R. [18991900/1965], iii-xi.

Durham Y., Hirshleifer J., Vernon S. [1998], Do the Rich Get Richer and the Poor Poorer? Experimental Tests of a Model of power, American Economic Review, 88(4), 970-983.

Forrest A. [2002], Napoleon's Men, The Soldiers of the Revolution and Empire, London and New York, Hambledon and London.

Furet F. [1978], Penser la révolution française, Paris, NRF Gallimard.

Furet, F. [1980/2006], The French Revolution Revisited, in: Kates G. (ed.), The French Revolution, recent Debates and New Controversies, second edition, New York, Routledge, 53567.

Goldstone J. [1998], Introduction, in Goldstone J.A. (ed.), The Encyclopedia of Political Revolutions, Washington, D.C., Congressional Quarterly Inc., xxxi-xxxviii.

Goldstone, J. [2009], Rethinking Revolutions: Integrating Origins, Processes, and Outcomes, Comparative Studies of South Asia, Africa and the Middle East, 29(1), 18-32. 
Hearder H. [1986], Editor's Foreword, in: Blanning T., The origins of the French revolutionary wars, London and New York: Longman Group Limited.

Herrmann Mascard N. [1991], Finalités modernes pour un impôt révolutionnaire : l'emprunt forcé de l'an II, in: Etat, finances et économie pendant la Révolution française, Paris, Comité pour l'histoire économique et financière de la France, 365-398.

Hirschman A. [1970], Exit, Voice, and Loyalty, Cambridge, Cambridge University Press.

Hirschman A. [1974], Exit, Voice, and Loyalty: Further Reflections and A Survey of Recent Contributions, Social Science Information, 13(1), 7-26.

Hirschman A. [1982], Shifting Involvements, Private Interest and Public Action, Princeton, NJ: Princeton University Press.

Hirshleifer J. [1991], The Paradox of Power, Economics and Politics, 3, 177-200.

Hirshleifer J. [1995], Anarchy and its breakdown, Journal of Political Economy, 103, 25-52.

Hirshleifer J. [2001], The Dark Side of the Force, Economic Foundations of Conflict Theory, Cambridge, Cambridge University Press.

Hobsbawm E. [1994], The Age of Extremes: The Short Twentieth Century 1914-1991, London: Michael Joseph.

Hobsbawm E., Ranger T. (eds.) [1988], The Invention of Tradition, New York: Cambridge University Press.

Hodgson G. [2015], Much of the 'economics of property rights' devalues property and legal rights, Journal of Institutional Economics, 11(4), 1-27.

Hodgson G. [2017], 1688 and all that: property rights, the Glorious Revolution and the rise of British capitalism, Journal of Institutional and Theoretical Economics, 13(1), 79-107.

Jessenne J-P. [2012], Robespierre, au défi de l'égalité et des politiques sociales, in: Robespierre. Portraits croisés, Paris, Armand Colin, 145-160.

Jones C. [2006], Bourgeois revolution revivified: 1789 and social change, in: Kates G. (ed.), The French Revolution, recent Debates and New Controversies, second edition, New York: Routledge, 87-112.

Kornai J. [1991], The Soviet Union's road to a free economy, comments of an outside observer, Tanner Lecture (part II), delivered at Leningrad University, June 13.

Kornai J. [1995], Transformational recession: a general phenomenon examined through the example of Hungary's development, in: Kornai J., Highways and Byways, Cambridge, MA: MIT Press, 161-208.

Kreps D. [1990], A Course in Microeconomic Theory, New Jersey: Princeton University Press. 
Labrousse E. [1990], La crise de l'économie française à la fin de l'Ancien Régime et au début de la Révolution, Paris: Presses universitaires de France.

Lange O. [1958], "The role of planning in socialist economy", Indian Economic Review, 4(2), 115 .

Lawson G. [2017], Negotiated Revolutions, the Czech Republic, South Africa and Chile, London and New York: Routledge.

Lenin V.I. [1915/1974], "The Collapse of the Second International”, Collected Works, Moscow: Progress Publishers, 205-259.

Leuvers H. [2014], Robespierre, Paris: Fayard

Mallet du pan J. [1798/2009], Considérations sur la nature de la Révolution de France et sur les causes qui en prolongent la durée, Ebook, WorldCat, consulted on January 29, 2020.

Mann M. [1986], The Sources of Social Power, A history of power from the beginning to A.D. 1760, Volume I, New York: Cambridge University Press.

Margairaz D. [1991], Le maximum : une grande illusion libérale ou la vanité des politiques économiques, in: Etat, finances et économie pendant la Révolution française, Paris: Comité pour l'histoire économique et financière de la France, 399-428.

Markoff J. [2006], Violence, emancipation, and democracy: the countryside and the French Revolution, in: Kates G. (ed.), The French Revolution, recent Debates and New Controversies, second edition, New York: Routledge, 165-197.

Marx K. [1852/1999], The Eighteenth Brumaire of Louis Bonaparte, translated by Zodiac and Brian Baggins, Marx/Engels Internet Archive (Marxist.org).

McPhee P [2013a], Introduction, in: McPhee P. (ed.), A companion to the French Revolution, West Sussex: Blackwell Publishing Ltd.

McPhee P. [2013b], The Economy, Society, and the Environment, in: McPhee P. (ed.), A companion to the French Revolution, West Sussex: Blackwell Publishing Ltd., 454-469.

North D. [1981], Structure and change in economic history. New York: W.W. Norton and Company.

North D. [1988], Ideology and Political/Economic Institutions, Cato Journal, 8(1), 15-28.

North D. [1990a], Institutions, Institutional Change and Economic Performance, Cambridge: Cambridge University Press.

North D. [1990b], A Transaction Cost Theory of Politics, Journal of Theoretical Politics, 2(4), $355-367$.

North D., Wallis J., Weingast B. [2009], Violence and social orders: A conceptual framework for interpreting recorded human history, New York: Cambridge University Press. 
North D., Wallis J., Webb S., Weingast B. (eds.) [2013], In the Shadow of Violence, Politics, Economics, and the Problems of Development, Cambridge: Cambridge University Press.

Olsson-Yaouzis, N. [2012], An evolutionary dynamic of revolutions, Public Choice, 151, 497515

Perlman S. [1945/1970], John Rogers Commons 1862-1945, The American Economic Review, 35(4), 782-86.

Pincus S. [1998], British "Glorious Revolution” (1688-1689), in: Goldstone J.A. (ed.), The Encyclopedia of Political Revolutions, Washington, D.C.: Congressional Quarterly Inc., 52-55.

Pinsard N. et Tadjeddine Y. (2019), L'édit de la Paulette 1604 : la marchéisation des finances royales, Revue d'économie financière, 135(3), 273-280.

Plack N. [2013], The Peasantry, Feudalism, and the Environment, 1789-93, in: McPhee P. (ed.), A Companion to The French Revolution, The Atrium: Wiley Blackwell Ltd., 212-227.

Plessis A. [1991], De la Caisse d'escompte à la Banque de France, in: Etat, finances et économie pendant la Révolution française, Paris: Comité pour l'histoire économique et financière de la France, 253-260.

Rouanet L. [2019], The interest group origins of the Bank of France, Public choice, on line, https://doi.org/10.1007/s11127-019-00765-6.

Sánchez-Pagés, S. [2009], Conflict as a part of the bargaining process', The Economic Journal, 119, 1189-1207.

Schiedel W. [2017], The Great Leveler, Violence and the History of Inequality from the Stone Age to the Twenty-First Century, Princeton and Oxford: The Princeton University Press.

Schumpeter J.A. [1951], Capitalism, Socialism, and Democracy, London, George Allen \& Unwin.

Skocpol, T. [1976a], France, Russia and China: A Structural Analysis of Social Revolutions, Comparative Studies in Society and History, 18, 175-210.

Skocpol T. [1976b], Old Regime Legacies and Communist Revolutions in Russia and China, Social Forces, 55, 284-315.

Skocpol T. [1979], States and Social revolutions in France, Russia, and China, New York: Cambridge University Press.

Skocpol T., Trimberger E. [1977-1978], Revolutions and the World-Historical Development of Capitalism, Berkeley Journal of Sociology, 22, 101-113.

Soboul A. [1982], La Révolution française, Paris: Gallimard, Tel.

Soboul A. [2006], The French Revolution in the history of the contemporary world, in: Kates G. (ed.), The French Revolution, recent debates and new controversies, second edition, New York: Routledge, 23-43. 
Sugden R. [1989], Spontaneous Order, Journal of Economic Perspectives, 3(4), 85-97.

Tackett T. [2006], Nobles and Third Estate in the revolutionary dynamic of the National Assembly, 1789-90, in: Kates G. (ed.), The French Revolution, recent debates and new controversies, second edition, New York: Routledge, 192-235.

Tazdait T. and Nessah R. [2008], Les théories du choix révolutionnaire, Paris : La découverte, coll. Repères.

Tilly C. [1985], War making and state making as organized crime, in: Evans P., Rueschemeyer D., Skocpol T. (eds.), Bringing the state back in, Cambridge: Cambridge University Press, 169191.

Trimberger E. [1972], A Theory of Elite Revolutions, Studies in Comparative International Development, 7, 191-207.

Trimberger E. [1977], State Power and Mode of Productions: Implications of Japanese Transition to Capitalism, The Insurgent Sociologist, 7, 85-98.

Trimberger E., [1978], Revolution From Above: Military Bureaucrats and Modernization in Japan, Turkey, Egypt and Peru, New Brunswick, New Jersey: Transaction Books.

Vahabi M. [2004], The Political Economy of Destructive Power, Cheltenham, Edward Elgar.

Vahabi M. [2009], A Critical Review of Strategic Conflict Theory and Socio-political Instability Models, Revue d'Economie Politique, 119(6), 817-858.

Vahabi M. [2010], Integrating Social Conflict into Economic Theory, Cambridge Journal of Economics, 34(4), 687-708.

Vahabi M. [2011], Appropriation, Violent Enforcement and Transaction Costs: A Critical Survey, Public Choice, 147(1), 227-253.

Vahabi M. [2012], Political Economy of Conflict - Foreword, Revue d'Economie Politique, 122(2), 151-167.

Vahabi M. [2016], The Political Economy of Predation: Manhunting and the Economics of Escape, New York: Cambridge University Press.

Vahabi M. [2019], Socialism and Kornai's revolutionary perspective, Public Choice, https://doi.org/10. 1007/s11127-019-00720-5.

Vahabi M., Batifoulier P., Da Silva N. [2020], A theory of predatory welfare state and citizen welfare: the French case, Public Choice, 182(3-4), 243-271.

Veblen T. [1899/1994], The Theory of the Leisure Class, New York: Dover Publications, Inc.

Woronoff D. [1991], Economie de guerre et intervention de l'Etat, in : Etat, finances et économie pendant la Révolution française, Paris: Comité pour l'histoire économique et financière de la France, 283-294. 
